\title{
多層路面雪永状態モデル Multilayered Snow/Ice Model on Road
}

\author{
藤 本 明 宏*1 ・渡 邊洋*2 \\ Akihiro Fujimoto Hiroshi Watanabe \\ 福 原 輝 幸*3 \\ Teruyuki Fukuhara
}

\section{SYNOPSIS}

A road covered with multilayered snow/ice (s/i) model called 'multilayer model' was proposed in this paper and applied to the melting process of $\mathrm{s} / \mathrm{i}$ layer on a pavement block in a low temperature room.

Consequently, it was found that (1) the multilayer model could reproduce reduction of the thickness of the $\mathrm{s} / \mathrm{i}$ layer, the volumetric ice content and temperature better than our previous model, i.e., the single layer model, (2) an accurate analysis of the melting process of the s/i layer requires that the element size (thickness) should be chosen less than 0.2 of the initial layer thickness, (3) the energy balance is effective in understanding the melting process of the $\mathrm{s} / \mathrm{i}$ layer.

Keywords : heat and mass transfer, road snow/ice condition, snow melting, multilayer model

\section{1.はじめに}

路面雪水状態は，大気，車両および舗装間の熱・ 水分移動に支配され，凍結防止剤散布下ではこれに 化学反応熱が新たに加わる。この熱・水分移動の複 合的振舞いを体系的にモデル化できれば，シミュレー ションによって任意の交通条件における凍結防止剂 散布後の路面雪水状態が求まり，効果的な散布時期 と量を前もって知ることが可能になる。

本研究では機械除雪される道路を対象として，路 面雪水層は厚さ $5 \mathrm{~cm}$ 程度までに限定する。筆者ら は路面雪水層を一様と近似する単一層路面雪水状態 モデル (Single-layer model, SLM) を提案した ${ }^{1)} 。$ 前 報2)では, SLM の妥当性を検証するために，融解過 程における雪水温度，雪水厚および質量含水率の実 験值と計算值を比較した結果，雪水厚が $20 \mathrm{~mm}$ 以 下では実用的な精度で再現できたがそれ以上になる と誤差が大きくなることが示された。

この要因は，（i）融解する雪水層のコントロール ボリュームが単一層では大きすぎること，(ii）雪水 内部の熱伝導および融解による水分（融水水）移動 が考慮されていないこと，が指摘された。

そこで本論文では, 雪水内部の伝導熱や融水水の 下方浸透に伴う顕熱を考慮した多層路面雪水状態モ デル（Multilayer model, MLM）を提案するとともに, 適切な雪水層の分割要素厚を論じ，雪水層の融解過 程を熱・水分移動の観点から考察する。

\section{2. 熱・水分移動理論}

ここでは図ー1を用いて，MLM における大気 一路面雪水層一舗装間の熱, 水分および空気移動の 概念を説明し，次に基礎方程式を提示する。図中の 熱，水分および空気の各フラックスについては，前 報 ${ }^{2)}$ で詳しく記載したので，MLM で新たに考慮す る雪水内部の伝導熱求よび融水水の下方浸透に伴う 顕熱のみ記述する。

\section{* 1 福井大学 VBL 博士研究員 \\ * 2 福井大学 特別研究員 \\ * 3 福井大学大学院 工学研究科}

[本稿受理：2007年 6 月 6 日, 修正原稿受理：2007年10月19日，討論期限：2008年12月31日] 


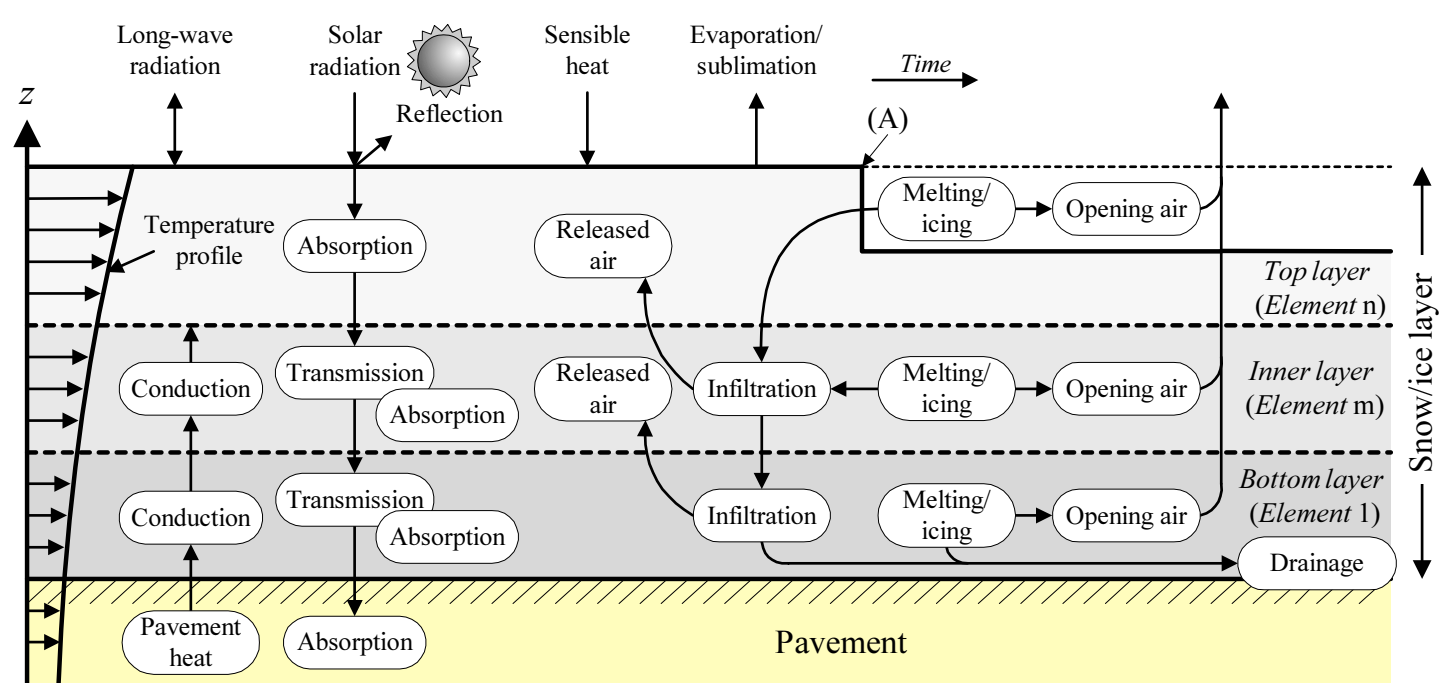

図－1 MLM における大気一路面雪水層－舗装間の熱, 水分および空気移動の概念図

\section{1 仮定}

本解析は, 以下の仮定の下で行う。

（i）通過車両や凍結防止剂の人為要因，降雨降雪 および道路勾配に伴う融水水の道路系外への 排水はない。

（ii）雪水の粘性圧縮および雪水内部の蒸発・昇華 はない。

（iii）鉛直方向の熱，水分および空気移動は一様に 起こるものとし, 道路縱横断方向の熱・水分 移動は考慮しない。

（iv）舗装は密粒度舗装として, 融水水の舗装面下 への浸透はない。

\section{2 多層路面雪水状態モデルの概念}

図ー 1 に示すように, MLM では雪水を $\mathrm{n}$ 層に分 割し, 底層を第 1 層, 任意の内部層を第 $\mathrm{m}$ 層, 表 層を第 $\mathrm{n}$ 層とする。

各雪水層の温度は熱収支より, コントロールボリュー ムおよび水・氷・空気の体積割合は, 水・水質量収 支（式(1)・式 (2) を参照) および空気体積収支（式 （3）を参照）よりそれぞれ求められる。雪水温度 $T_{s}<$ $0{ }^{\circ} \mathrm{C}$ であれば，雪水層の純熱フラックス $Q_{n}$ （式 (4) または式(5)を参照) によって， $T_{s}$ のみ変化し, 新 たな融解・凝固は生じない。 $T_{s}=0^{\circ} \mathrm{C}$ かつ $Q_{n}>0$ で あれば融解, 逆に $Q_{n}<0$ であれば凝固が生じる。例 えば, 図ー 1 中の (A) に示すように表層から融解が
生じるとすれば, $\mathrm{n}$ 層では雪水密度の増加（含水率 の増大）と同時に, 融解前まで雪水層としてコント ロールボリュームを形成していた空気の一部が大気 に開放され, 雪水厚が小さくなる。融水水は氷粒子 間の表面張力により一時的に $\mathrm{n}$ 層に保持されるが,

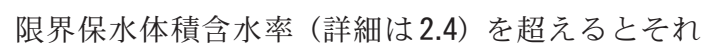
より 1 つ下の層へ浸透するものとする。 $\mathrm{m}$ 層がその 直上の $\mathrm{m}+1$ 層からの浸透水を受け取ると, それと 同体積の空気が $\mathrm{m}+1$ 層へ押しやられる（浸透水と 空気との置換)。こうして, 融水水はより下層へ移 動し, 舗装と接する第 1 層で貯留される。

融解が進行し, $\mathrm{n}$ 層が設定した微小厚以下になる と, $\mathrm{n}$ 層の水, 水および空気を $\mathrm{n}-1$ 層に加え, $\mathrm{n}$ 層 を消失する。代わって, n-1 層が表層となる。

\section{3 基礎方程式}

\subsection{1 水分および空気移動理論}

図一 1 に従い, 単位水平面積当たりの路面雪水表 層の水質量 $M_{w}\left(\mathrm{~kg} / \mathrm{m}^{2}\right)$, 水質量 $M_{i}\left(\mathrm{~kg} / \mathrm{m}^{2}\right)$ および空 気体積 $V_{a}\left(\mathrm{~m}^{3} / \mathrm{m}^{2}\right)$ の時間変化率は, 以下の式で表さ れる。

$$
\begin{aligned}
& \text { 水質量 }: \frac{\partial M_{w}}{\partial t}=M_{w i}+M_{w i}+M_{w s} \\
& \text { 皮質量 }: \frac{\partial M_{i}}{\partial t}=M_{i l}-M_{w i}
\end{aligned}
$$




$$
\text { 空気体積 }: \frac{\partial V_{a}}{\partial t}=-V_{a e x}-V_{a o}
$$

ここに, $M_{w l}$ : 蒸発・凝結フラックス $\left(\mathrm{kg} / \mathrm{m}^{2} / \mathrm{s}\right)$, $M_{w i}$ : 融解・凝固フラックス $\left(\mathrm{kg} / \mathrm{m}^{2} / \mathrm{s}\right), M_{w s}$ : 融水水 の下方浸透フラックス $\left(\mathrm{kg} / \mathrm{m}^{2} / \mathrm{s}\right), M_{i l}$ : 昇華フラッ クス $\left(\mathrm{kg} / \mathrm{m}^{2} / \mathrm{s}\right), V_{a e x}$ : 置換空気フラックス ${ }^{1)}\left(\mathrm{m}^{3} / \mathrm{m}^{2} / \mathrm{s}\right)$, $V_{a o}$ : 開放空気フラックス ${ }^{1)}\left(\mathrm{m}^{3} / \mathrm{m}^{2} / \mathrm{s}\right)$ および $t$ : 時間 (s)である。

\subsection{2 熱移動理論}

路面雪水を構成する要素（雪水分割要素）の熱収 支は，図－1に従い以下の式で表される。

表層 :

$$
\begin{aligned}
\frac{\partial}{\partial t}\left\{(\rho c)_{s} z_{s} T_{s}\right\} & =C_{i}+R_{s a}+R_{n l}+S_{a}+S_{m}-L_{e}+L_{m} \\
& =Q_{n}
\end{aligned}
$$

内部および底層 :

$$
\frac{\partial}{\partial t}\left\{(\rho c)_{s} z_{s} T_{s}\right\}=C_{i}+C_{s p}+R_{s a}+S_{m}+L_{m}=Q_{n}
$$

ここに, $(\rho c)_{s}$ : 雪水分割要素の体積熱容量 $\left(\mathrm{J} / \mathrm{m}^{3} / \mathrm{K}\right)$, $z_{s}$ : 雪水分割要素厚 $(\mathrm{m}), C_{i}$ : 純伝導熱フラックス $\left(\mathrm{W} / \mathrm{m}^{2}\right), R_{s a}$ : 日射の吸収熱フラックス $\left(\mathrm{W} / \mathrm{m}^{2}\right), R_{n l}$ : 純長波放射熱フラックス $\left(\mathrm{W} / \mathrm{m}^{2}\right), S_{a}$ : 自然風に伴 う顕熱フラックス $\left(\mathrm{W} / \mathrm{m}^{2}\right), S_{m}$ : 融水水の下方浸透 に伴う顕熱フラックス $\left(\mathrm{W} / \mathrm{m}^{2}\right), L_{e}$ : 蒸発・昇華潜 熱フラックス $\left(\mathrm{W} / \mathrm{m}^{2}\right), L_{m}$ : 融解・凝固潜熱フラッ クス $\left(\mathrm{W} / \mathrm{m}^{2}\right)$ および $C_{s p}$ : 舗装熱フラックス $\left(\mathrm{W} / \mathrm{m}^{2}\right)$ である。ただし， $C_{s p}$ は底層のみに作用し， $(\rho c)_{s}$ お よび $z_{s}$ は式 (1)〜（3）を基に水，水および空気の体 積割合より時間ステップ毎に計算される1）。当然な がら， $z_{s}$ の総和は雪水層厚に等しい。

\section{4 雪水層内部を移動する熱フラックス}

$C_{i}$ は, Fourier の法則に従い計算される。ただし, 雪水の平均熱伝導率 $\lambda_{s}$ は水, 水および空気の熱伝 導率と体積割合を基に計算される1)。

次に, $S_{m}$ について述べる。一般的に, 気一液一 固相から成る混合物中の水分移動は, Darcy 則に準 じて毛管ポテンシャルと重力ポテンシャルによって 規定される。しかしながら，路面雪水層では水の粒 径および形状が不規則かつ複雑に変化するために, 毛管ポテンシャルを正確に求めることは難しい。従つ
て, 土壤の水分特性曲線で知られるように, 毛管ポ テンシャルは体積含水率が増大するにつれて減少し, 保水能力が低下するものと考える。そこで, 雪水層 の体積含水率がある限界值（限界保水体積含水率 $\theta_{w c}$ ）を超えると融水水の下方浸透が生じるという仮 定を設ける。ここでは, 下方浸透は計算の時間間隔 $\Delta t$ で完了すると仮定し， $M_{w s}$ を式(6)で与える。

$$
M_{w s}=-\frac{\rho_{w}\left(V_{w}-V_{s} \theta_{w c}\right)}{\Delta t}
$$

ここに, $\rho_{w}$ : 水の密度 $\left(\mathrm{kg} / \mathrm{m}^{3}\right), V_{s}$ : 単位水平面積 当たりの雪水体積 $\left(\mathrm{m}^{3} / \mathrm{m}^{2}\right), V_{w}: V_{s}$ に含まれる水体 積 $\left(\mathrm{m}^{3} / \mathrm{m}^{2}\right)$ である。なお，本モデルでは $\mathrm{Gerdel}^{3)}$, 前野・福田 ${ }^{4)}$, 山崎 $~^{5)}$, 岩倉・佐藤 ${ }^{6)}$ の報告を参 考に $\theta_{w c}=0.02$ とした。

従って $S_{m}$ は, 上述の $M_{w s}$ を用いて, 式(7)で与え られる。

$$
S_{m}=c_{w} M_{w s} T_{s}
$$

ここに, $c_{w}$ : 水の比熱 $(\mathrm{J} / \mathrm{kg} / \mathrm{K})$ である。

\section{3. 実験值と計算値の比較検討 \\ 3.1 融雪実験}

融雪実験では，低温恒温室で赤外線放射ランプを 用いて密粒度舗装上の人工雪を融解させる。その際, $T_{s}$ および舗装温度 $T_{p}$, 雪水厚 $H_{s}(\mathrm{~mm})$, 質量含水 率 $\Theta_{i}$ および雪密度 $\rho_{s}\left(\mathrm{~kg} / \mathrm{m}^{3}\right)$ を測定する。

実験は, 初期の雪水状態を $\Theta_{i}=1.0$ (乾燥雪) と $\rho_{s}$ = 約 $500 \mathrm{~kg} / \mathrm{m}^{3}$ に統一して, 初期の $H_{s}, H_{s 0}=10,20$ お よび 30mm（Case 1, Case 2 および Case 3) の 3 ケー スとした。

なお，実験の詳細は参考文献 1 ) および 2 )を参照 されたい。

\section{2 計算結果}

\section{2 .1 雪水温度および舗装温度}

図－2(a)，(b) および (c) は, Case 1, Case 2お よび Case 3 における気温 $T_{a}\left({ }^{\circ} \mathrm{C}\right), T_{s}$ および $T_{p}$ の鉛 直分布の経時変化である。図中には, 点線で SLM による $T_{s}$ および $T_{p}$ の計算值， $T_{s s}\left({ }^{\circ} \mathrm{C}\right)$ および $T_{p s}\left({ }^{\circ} \mathrm{C}\right)$, 実線で MLM による $T_{s}$ および $T_{p}$ の計算值, $T_{s m}\left({ }^{\circ} \mathrm{C}\right)$ および $T_{p m}\left({ }^{\circ} \mathrm{C}\right)$, 塗潰しのシンボル $(\bigcirc)$ およ 


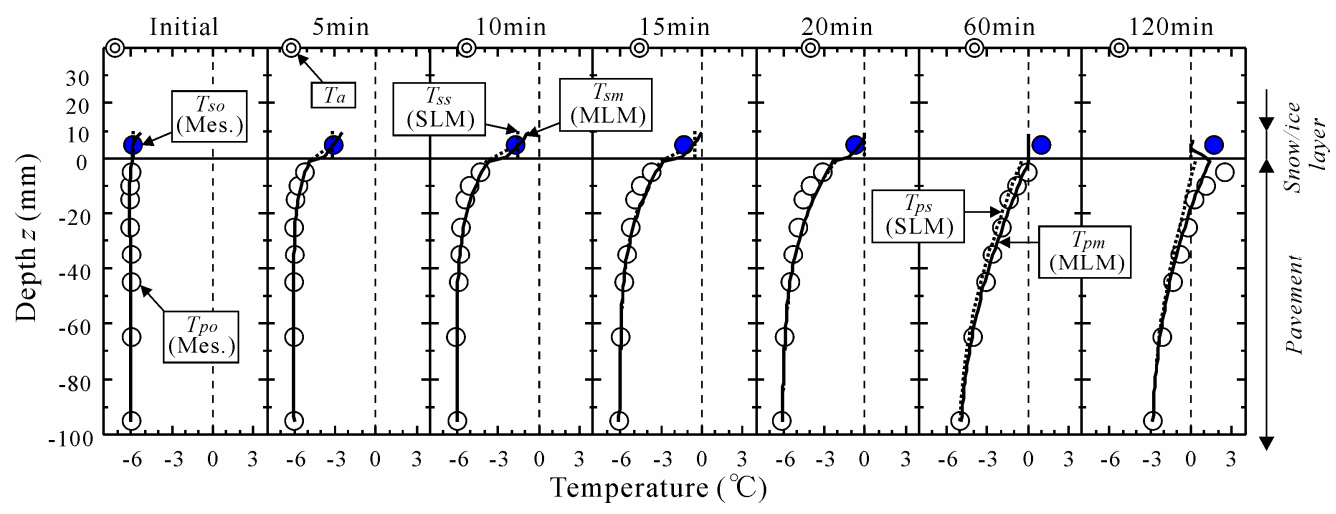

(a) Case $1\left(H_{s 0}=10 \mathrm{~mm}\right)$

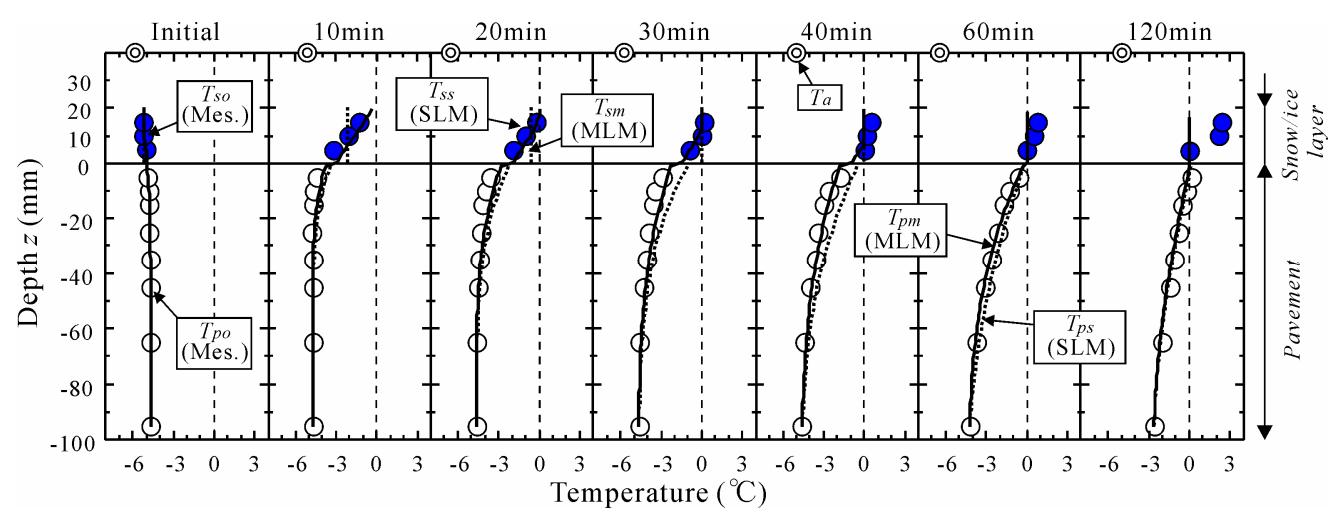

(b) Case $2\left(H_{s 0}=20 \mathrm{~mm}\right)$

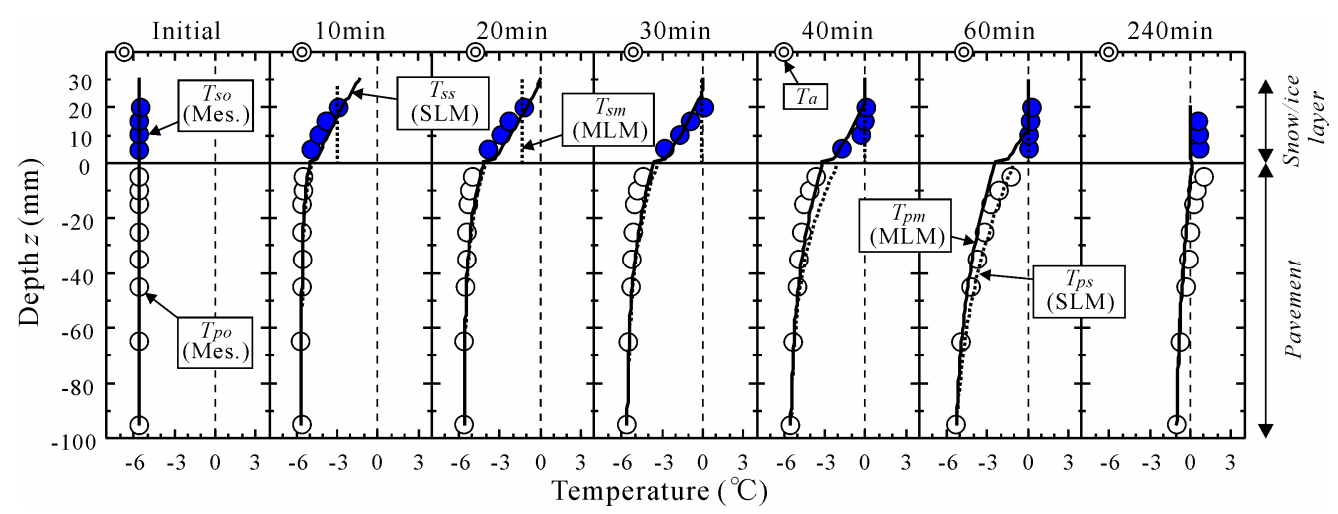

(c) Case $3\left(H_{s 0}=30 \mathrm{~mm}\right)$

図-2 雪水および舗装の鉛直温度分布の経時変化

び白抜きのシンボル $(\bigcirc)$ で $T_{s}$ および $T_{p}$ の実験值, $T_{s o}\left({ }^{\circ} \mathrm{C}\right)$ および $T_{p o}\left({ }^{\circ} \mathrm{C}\right)$, 二重丸のシンボル (@) で $T_{a}$ の実験值，をそれぞれ示す。なお，以下の下付き添 字 $s$ はSLM の計算值を, $m$ は MLM の計算值を, $o$ は実験值をそれぞれ意味する。また，MLM では計
算開始時の $z_{s}, z_{s 0}$ は $1 \mathrm{~mm}$ とした。

まず，(a) Case 1 について記述する。 $T_{a}$ は $-5^{\circ} \mathrm{C} に$ 設定したが冷凍機の制約を受けて設定值の $\pm 2.0^{\circ} \mathrm{C}$ の範囲で変動した。実験開始時の $T_{s o}$ および $T_{p o}$ は, 一様に $-6.0^{\circ} \mathrm{C}$ である。 $T_{s o}$ は放射ランプからの熱供 


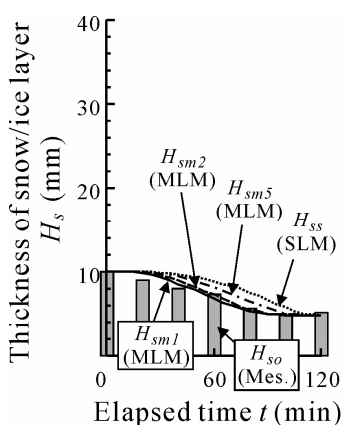

(a) Case $1\left(H_{s 0}=10 \mathrm{~mm}\right)$

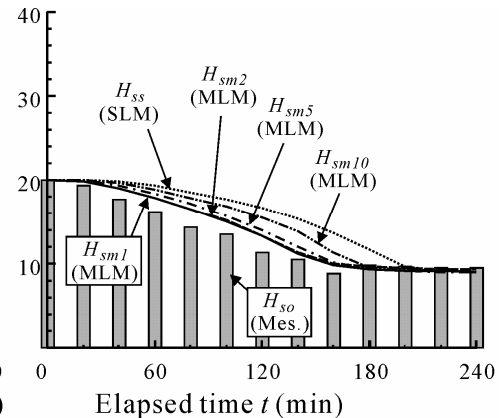

(b) Case $2\left(H_{s 0}=20 \mathrm{~mm}\right)$

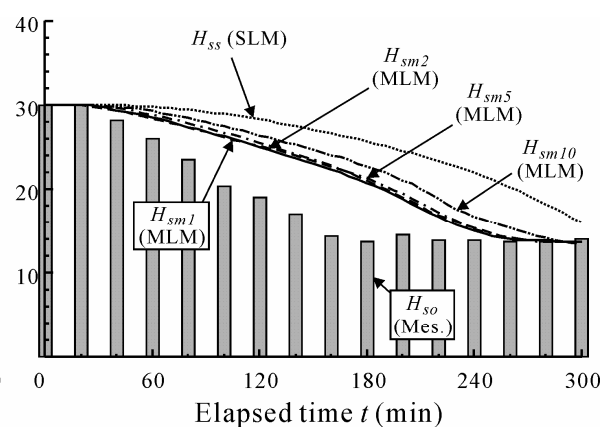

(c) Case $3\left(H_{s 0}=30 \mathrm{~mm}\right)$

\section{図-3 雪水厚の経時変化}

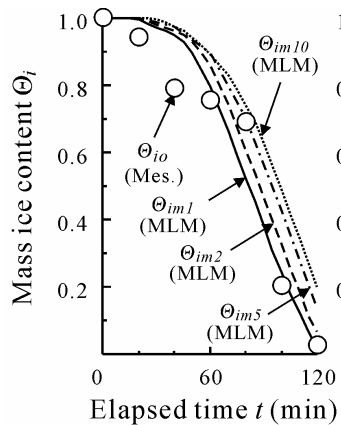

(a) Case $1\left(H_{s 0}=10 \mathrm{~mm}\right)$

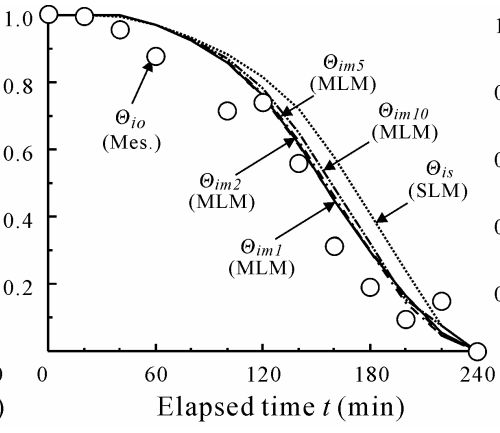

(b) Case $2\left(H_{s 0}=20 \mathrm{~mm}\right)$

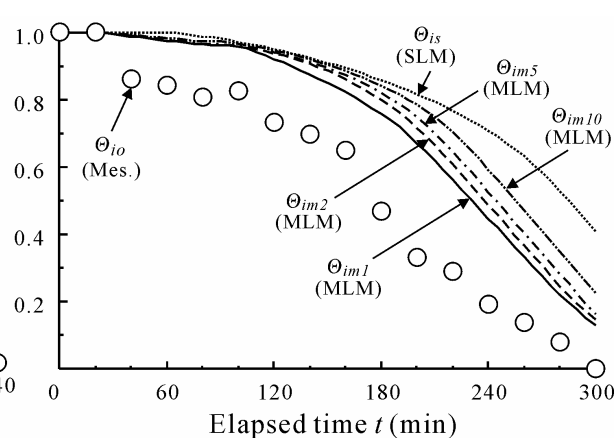

(c) Case $3\left(H_{s 0}=30 \mathrm{~mm}\right)$

\section{図-4 質量含水率の経時変化}

給により上昇し, $t=120$ 分後では正の值をとる。 $T_{p o}$ は $T_{s o}$ の上昇に引きずられて舗装表面から上昇し, 舗装全体が昇温する。

次に, $T_{s}$ の計算結果を見ると, $T_{s m}$ は雪水表層か ら温度上昇が起こり，ほぼ線形的な温度分布となる

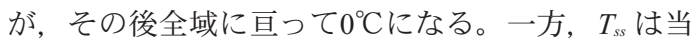
然ながら一様に上昇する。両者の関係は雪氷表層付 近で $T_{s s}<T_{s m}$, 雪水底層付近で $T_{s s}>T_{s m}$ であり, $T_{s s}$ は $T_{s m}$ の平均的な值を推移する。 $t=15$ 分に注目する と, $T_{s s}=$ 約 $-1{ }^{\circ} \mathrm{C}$ に対して, 雪水表層の $T_{s m}=0{ }^{\circ} \mathrm{C}$ であ ることから, MLM では SLM より早く融解が発生 する。

次に, (c) Case 3 について述べる。傾向は Case 1 と同様であるが, $d T_{s m} / d z$ は Case 1 より大きい。表 層の $T_{s m}$ は $t=20$ 分で $0{ }^{\circ} \mathrm{C}$ 到達し, その後 $T_{s m}=0^{\circ} \mathrm{C}$ の領域は下方へ広がる。それに対して, $T_{s s}$ は $t=30$ 分でさえ氷点下にあり, MLM と SLM 間の融解発
生時間差は Case 1 に比べてより明瞭になる。

各ケースの $T_{s m}$ は $T_{s o}$ と良好に一致しており, MLM は融解過程における雪水層内の温度分布を再現する ことができた。

\section{2 .2 雪水厚}

図ー3 (a)，(b) および (c) は, Case 1, Case 2 お よび Case 3 における $H_{s}$ の経時変化である。図中の 棒は実験值 $\left(H_{s o}\right)$ を, 点線は SLM の計算值 $\left(H_{s s}\right)$, 実線，破線，一点破線および二点破線は $z_{s 0}=1,2,5$ および $10 \mathrm{~mm}$ における MLM の計算值 $\left(H_{s m l}, H_{s m 2}\right.$, $H_{s m 5}$ および $\left.H_{s m l l o}\right)$ である。

まず，(a) Case 1 に着目する。 $H_{s o}(\mathbf{I})$ は, 実験開始 から $t=80$ 分まで直線的に低下し, $t=80$ 分以降では 雪水層が完全に融解したときの水深約 $5 \mathrm{~mm}$ になる。

雪水層の低下 (融解) 開始は, $H_{s s}$ では $t=27$ 分で あるのに対して， $H_{s m 5}, H_{s m 2}$ および $H_{s m l}$ ではそれぞ れ $t=21,20$ および19分のように早まり, 実際の融 


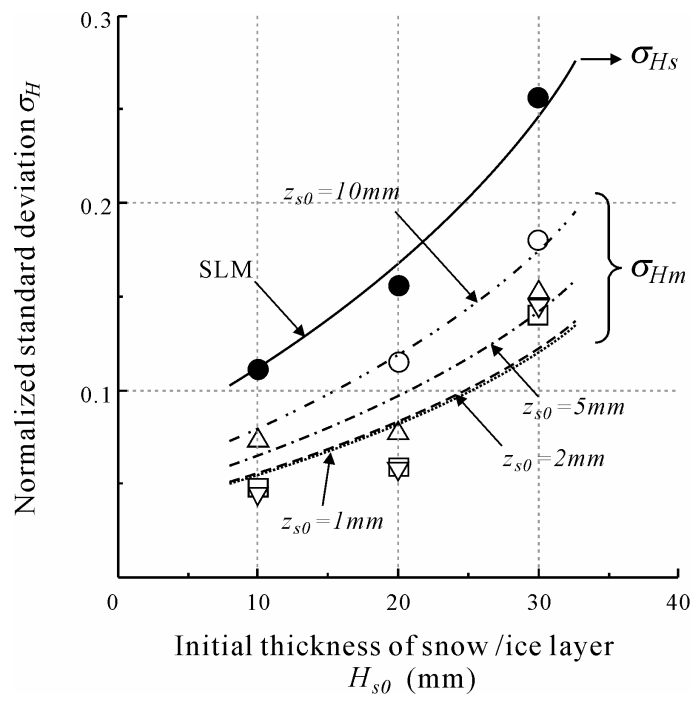

図－5初期雪水厚と計算誤差の関係

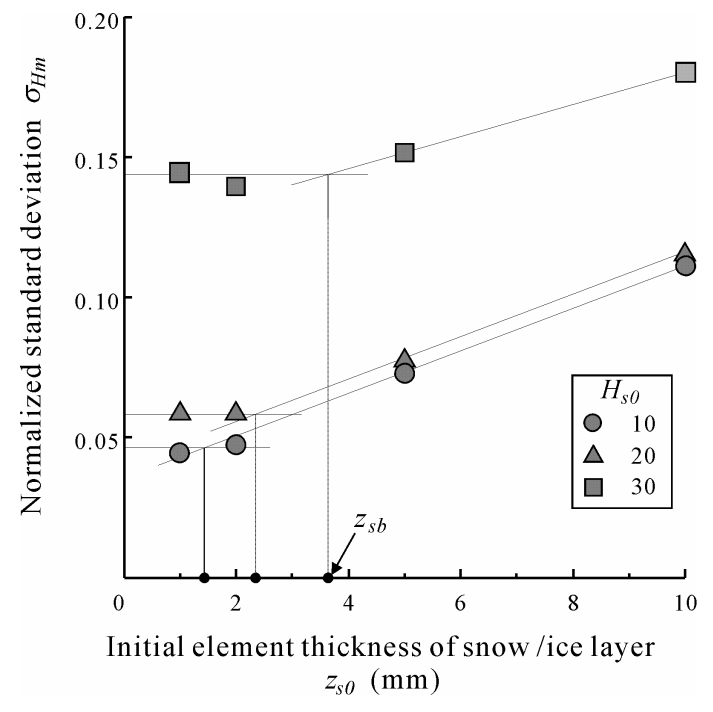

図－6 初期雪水分割要素厚と計算誤差の関係
解状況に近づく。このように, SLM に比べて MLM の方が，また $z_{s 0}$ が小さいほど計算精度は高まる。 この理由は先述したとおり， $Z_{s 0}$ が小さくなるにつ れて雪水表層の融解が適切に計算されていることに よる。

(b) Case 2 および (c) Case 3 でも Case 1 と同様に $Z_{s 0}$ を細かくするほど，計算精度は上がるものの， Case 1 よりも計算值と実験值の差は大きい。この理 由は，不飽和浸透の簡略的な表現方法および熱移動 に関連するパラメーター（アルベド，透過率および $\left.\lambda_{s}\right)$ に含まれる誤差などが考えられる。本来は，凍 結・融解を考慮した不飽和浸透流モデルを用いて水 分移動を解くべきであるが, マトリックポテンシャ ルや透水係数の決定は非常に複雑である。この不飽 和浸透解析が $\theta_{w}, \theta_{i}$ および $H_{s}$ に及ぼす影響を今後 調べる必要がある。

\subsection{3 質量含水率}

図ー4 (a), (b) および (c) は, Case 1, Case 2 お よび Case 3 における $\Theta_{i}$ の経時変化である。図中の 黒丸は実験值 $\left(\Theta_{i o}\right)$ を, 点線は SLM の計算值 $\left(\Theta_{i s}\right)$, 実線，破線，一点破線および二点破線は $z_{s 0}=1,2,5$ および $10 \mathrm{~mm}$ における MLM の計算值 $\left(\Theta_{i m l}, \Theta_{i m 2}\right.$, $\Theta_{i m 5}$ および $\left.\Theta_{i m 10}\right)$ である。
Case 1 の $\Theta_{i o}(\bigcirc)$ は, 時間経過につれ低下し, $t=$ 120 分でゼロになった。計算結果は, SLM より MLM で実験值に近づき， $z_{s 0}$ を細かくするほど実験 值との差が小さくなるものの, 実験結果より過大に 評価される。また，計算誤差は Case 1, Case 2 およ び Case 3 の順で大きい。

\section{3 計算誤差に関する検討}

図－５は， $H_{s 0}$ と無次元計算誤差 $\left(\sigma_{H}\right)$ の関係を示 しており， $\sigma_{H}$ は式 (8)で与えられる。

$$
\sigma_{H}=\frac{\sqrt{\frac{1}{n} \sum\left(H_{s o}-H_{s c}\right)^{2}}}{H_{s 0}}
$$

ここに, $H_{s c}: H_{s}$ の計算值および $n:$ サンプル数 (実 験での測定回数) である。

$H_{s 0}=20 \mathrm{~mm}$ に着目すると, SLM の $\sigma_{H}, \sigma_{H s}$ は 0.156 , $z_{s 0}=1,2,5$ および $10 \mathrm{~mm}$ で MLM の $\sigma_{H}, \sigma_{H m}$ はそれ

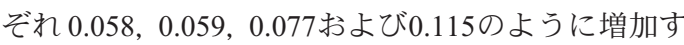
る。ただし， $z_{s 0}=1 \mathrm{~mm}$ と $2 \mathrm{~mm}$ の差異は極めて小さい。

同じ $z_{s 0}$ では, $H_{s 0}$ の増加とともに $\sigma_{H s}$ および $\sigma_{H m}$ は 下に凸のような形状で非線形的に増大する。また， そ の増加率は $z_{s 0}$ が厚くなるにつれ増大する傾向にある。

図－6は $\sigma_{H m}$ と $z_{s 0}$ の関係を示す。いずれの $H_{s 0}$ に おいても $z_{s 0}$ の減少に伴い $\sigma_{H m}$ は低下し, 一定值に 


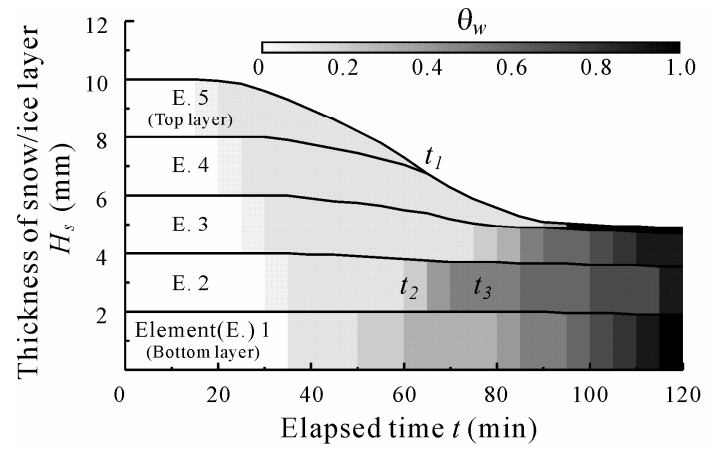

（a）体積含水率 $\theta_{w}$

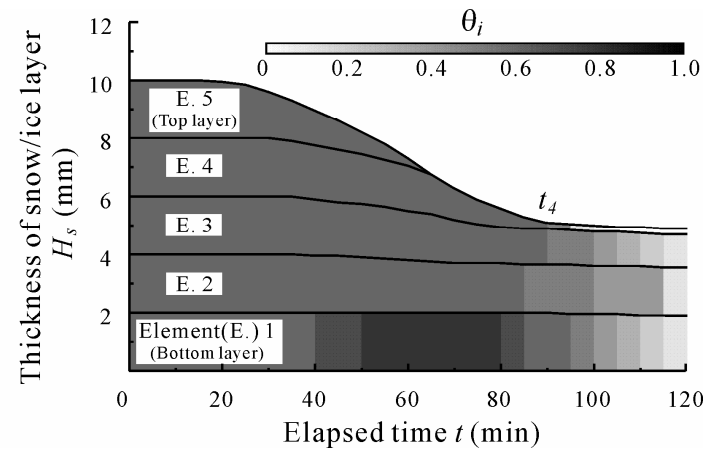

（b）体積含水率 $\theta_{i}$

図- 7 雪水厚, 体積含水率および体積含水率の経時変化

漸近する。

この結果より, MLMにおける適切な $z_{s 0}$ について 以下に述べる。図ー 6 中に示すように, $z_{s 0}=1 \mathrm{~mm}$ と $2 \mathrm{~mm}$ の $\sigma_{H m}$ に差が殆どないことから, これらの $\sigma_{H m}$ を結んだ水平線と $\sigma_{H m}$ の変化の大きい $z_{s 0}=5 \mathrm{~mm}$ と $10 \mathrm{~mm}$ を結ぶ直線の交点の $z_{s 0}$ を $z_{s b}$ とする。そこで, $z_{s b}$ と $H_{s 0}$ の比率 $R_{z}\left(=z_{s b} / H_{s 0}\right)$ を調べると, $R_{z}$ は $H_{s 0}=$ $10 \mathrm{~mm}$ で $0.14, H_{s 0}=20 \mathrm{~mm}$ で $0.12, H_{s 0}=30 \mathrm{~mm}$ で 0.12 となる。しかしながら $R_{z}=0.2$ であっても， $\sigma_{H m}$ は $R_{z}$ $=0.1$ と比べると, $H_{s 0}=30 \mathrm{~mm}$ で $0.14 \rightarrow 0.16, H_{s 0}=20$ $\mathrm{mm}$ で $0.06 \rightarrow 0.07, H_{s 0}=10 \mathrm{~mm}$ で $0.04 \rightarrow 0.05$ に増大 するだけで, 精度の低下は大きくない。

以上より, $H_{s 0}$ の 2 割程度が $z_{s 0}$ として望ましいと 考えられる。

\section{4. 多層路面雪水状態モデルを用いた融解 過程の考察}

ここでは, MLMによる計算結果から融解過程の 熱・水分移動および物性変化を詳しく考察する。計 算に用いた実験デー夕は Case $1\left(H_{s 0}=10 \mathrm{~mm}\right), z_{s 0}$ は $2 \mathrm{~mm}$ とした。雪水は 5 層に分割され，底層を E. 1 , 上層に向かって E. 2, E. 3, E. 4, 表層を E. 5 と呼ぶ。

\section{1 雪水物性}

図一 7 は, $H_{s}$, 体積含水率 $\theta_{w}$ および体積含水率 $\theta_{i}$ の経時変化を表したものであり, E. 1 から E. 5 に分 けて表示している。同図 (a) および (b) 中の色分 けは $\theta_{w}$ および $\theta_{i}$ の変化を意味し, 白から黒への変
化は $\theta_{w}$ および $\theta_{i}$ ともに 0 から 1.0 に対応する。

融解による $H_{s}$ の低下は, E. 5 から E. 1 に向かっ て順に生じ，その低下率も同順で小さくなる。図中 の $t_{l}$ は E. 5 が十分に小さくなったため消滅した時 間である。これ以降, E. 4 の低下 (融解) は促進する。

\subsection{1 体積含水率 $\theta_{w}$}

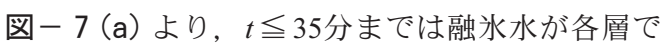
保持され, 融解は E. 5 から始まるために, $\theta_{\mathrm{w}}$ は E. 5 から E. 2 に向かって順次増大することが分かる。 その後, $\theta_{w}>\theta_{w c}$ になると融水水は下層に浸透する ために, E. 2 から E. 5 で $\theta_{w}$ は $\theta_{w c}$ を維持する。一方, E. 1 では浸透がないために， $\theta_{w}$ は時間とともに増 大し, 図中 $t_{2}$ の時間で飽和となる。従って, その 後は E. 2 に融水水が貯留されるようになり, E. 2 の $\theta_{w}$ は時間とともに増大する。

また，図中 $t_{3}$ に着目すると，E. 2 の $\theta_{w}>$ E. 1 の $\theta_{w}$ となっていることが分かる。これは, E. 1 では上層 からの浸透水の一部が再凍結することにより生じる ものである。この再凍結の原因は, E. 1 がそれより 低温な舗装に熱を奪われることによる（詳細は4.2)。 なお,この再凍結現象は目視でも観られた。

最終的に各層ともに $t=120$ 分で $\theta_{w}=1.0$ となった。

\subsection{2 体積含水率 $\theta_{i}$}

図ー7 (b) に示す $\theta_{i}$ について述べる。 $t=0$ の $\theta_{i}$ は 一様に 0.54 である。E. 1 の $\theta_{i}$ は $t=35$ 分から増大し, $t=63$ 分には最大 0.77 となり, 上述の再凍結が確認さ れる。E. 2 からE. 5 では, 図中 $t_{4}$ の時点まで融解に 
よって $V_{i}$ は減少するものの, $H_{s}$ も減少するために, 結 果的に $\theta_{i}$ は殆ど変化しない。しかしながら $t_{4}$ 以降， $\theta_{i}$ の低下は顕著となり, 最終の $t=120$ 分で $\theta_{i}=0$ となる。

\section{2 熱フラックス}

図-8の上段，中段および下段は，E. 5 ，E. 4 お よび E. 1 の熱収支の内, 絶対值の大きかった熱フ ラックス $R_{n s}, R_{n l}, C_{i}, C_{s p}$ および $L_{m}$ を示す（值の小 さかった $S_{a}, S_{m}$ および $L_{e}$ (は割愛)。また, 図中に示 す $\mathrm{P}_{\mathrm{r}}$ は $T_{s}$ の上昇期間, $\mathrm{P}_{\mathrm{m}}$ は融解期間および $\mathrm{P}_{\mathrm{f}}$ は再 凍結期間を, 添字は各々の出現番号を表す。同図縦 軸の正は雪水層への熱供給を, 負は熱損失を意味す る。なお, 以下の文章では, 負の熱フラックスの増 減は絶対值のそれと同じ表現とする。

先ず，E. 5 について説明する。 $\mathrm{P}_{\mathrm{r} 1}$ において， $R_{n s}$ （ム）は実験開始と同時に増大した後，一定となる。 $R_{n l}(\nabla)$ は $T_{s}$ の上昇に伴って雪水層からの長波放射 熱フラックスが増大するために微減となる。 $C_{i}(\mathbf{\square})$ は雪水層の温度勾配 $\partial T_{s} / \partial z_{s}$ が大きくなるために, 僅かに増大する。 $L_{m}(\bigcirc)$ は, 当初 0 である。 $\mathrm{P}_{\mathrm{m} 1}$ で は， $R_{n l}$ は殆ど変わらない。 $R_{n s}$ は融解に伴うアルベ ドの低下により増大する。また, $\partial T_{s} / \partial z_{s}=0\left(T_{s}=0\right.$ $\left.{ }^{\circ} \mathrm{C}\right)$ より $C_{i}=0$ となる。従って, E. 5 の融解の主要 因は $R_{n l}$ であるが，時間とともに $R_{n s}$ により融解が 促進される。この $R_{n s}$ および $R_{n l}$ による熱供給は $L_{m}$ によって消費される。

次に, E. 4 に着目する。E. 4 の素過程は同図中の $\mathrm{P}_{\mathrm{r} 2}, \mathrm{P}_{\mathrm{m} 2}, \mathrm{P}_{\mathrm{m} 3}$ および $\mathrm{P}_{\mathrm{r} 3}$ に分けられる。 $\mathrm{P}_{\mathrm{r} 2}$ では, $R_{n s}$ の熱供給は $C_{i}$ によって下方へ伝達される。 $\mathrm{P}_{\mathrm{m} 2}$ では, 融解に伴うアルベドの低下と E. 5 の透過率の増大 によって，Rns は増大する。そのため融解が促進し, $L_{m}$ は増大する。 $\mathrm{P}_{\mathrm{m} 3}$ では, $R_{n s}$ はアルベドの低下によ り一旦増大するもののその後, E. 4 の透過率が増大 することにより減少する。E. 4 が表層になったこと で $R_{n l}$ が発生し，その值は時間とともに減少する。 $R_{n s}$ に $R_{n l}$ が加わつたことにより, 融解に寄与するエネ ルギーが増大し，これと同等の值にまで $L_{m}$ は急増 する。その後, $L_{m}$ は $R_{n s}$ および $R_{n l}$ の減少に伴って 小さくなる。 $\mathrm{P}_{\mathrm{r} 3}$ の E. 4は, 完全に融解したため $L_{m}=$ 0 となり, $R_{n s}$ と $R_{n l}$ を加えた熱フラックスは $C_{i}$ によっ て下方へ輸送される。

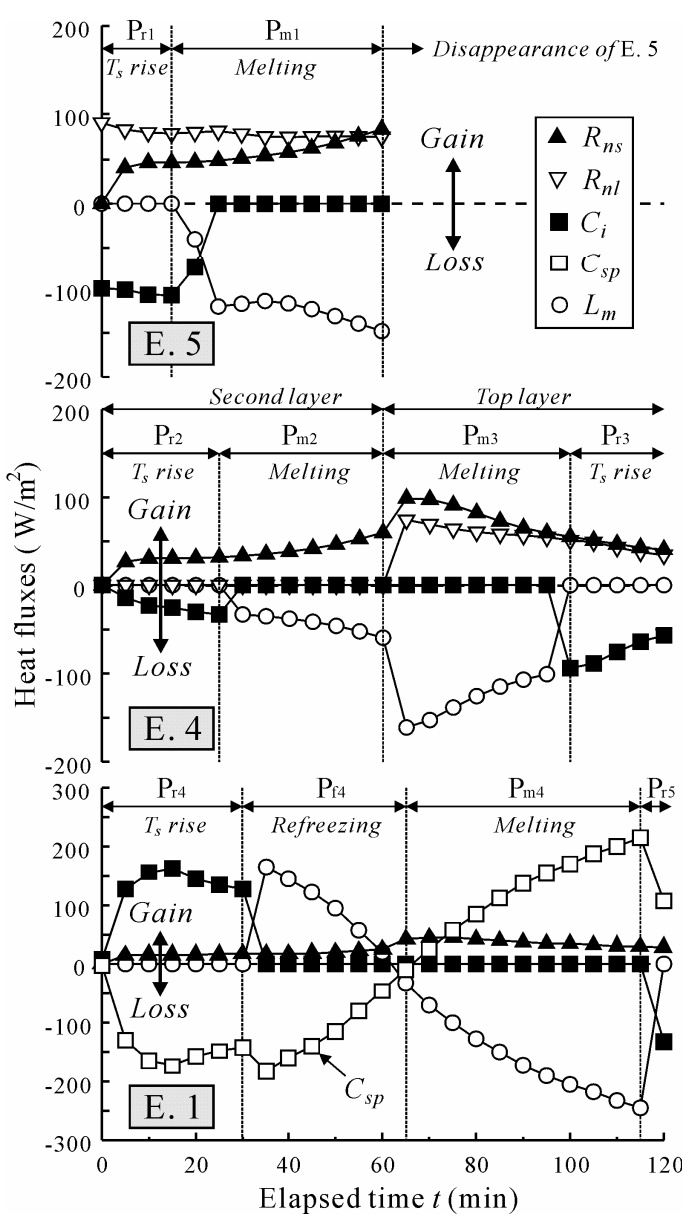

図－8＼cjkstart熱フラックスの経時変化

最後に, E. 1 について述べる。E. 1 の素過程は $\mathrm{P}_{\mathrm{r} 4}$, $\mathrm{P}_{\mathrm{fl}}, \mathrm{P}_{\mathrm{m} 4}$ および $\mathrm{P}_{\mathrm{r} 5}$ の 4つに大別される。 $\mathrm{P}_{\mathrm{r} 4}$ では, 上 層からの $C_{i}$ は $C_{s p}(\square)$ によって舗装へ輸送される。 $\mathrm{P}_{\mathrm{f} 1}$ では, 上層からの浸透水 $\left(0^{\circ} \mathrm{C}\right)$ の流入とほぼ同 時に, $\partial T_{s} / \partial z_{s}=0\left(T_{s}=0^{\circ} \mathrm{C}\right)$ となり, $C_{i}=0$ となる代わ りに $L_{m}>0$, すなわち凝固潜熱フラックスが発生す る。その後, $T_{p}$ の上昇に伴い, $C_{s p}$ および $L_{m}$ はとも に減少する。 $\mathrm{P}_{\mathrm{m} 4}$ では, $C_{s p}>0\left(T_{p}>0^{\circ} \mathrm{C}\right)$ によって, $L_{m}<0$, すなわち融解潜熱フラックスとなり, 時間 とともに増大する。 $\mathrm{P}_{\mathrm{r} 5}$ では, $C_{s p}$ と $R_{n s}$ の熱フラッ クスは $C_{i}$ によって上層へ輸送される。

なお，同図には示していないが， $S_{m}$ は一時的に 発生するものの, その絶対值は極めて小さい。これ は雪水層中の温度勾配, $\partial T_{s} / \partial z_{s} \fallingdotseq 0$ となるためであ る。 


\section{5.おわりに}

本論文では, 多層路面雪水状態モデルを構築し, 実験結果との比較から, 適切な雪水分割要素厚を提 案するとともに, 雪水層の融解過程を熱・水分移動 の観点から考察を行った。

その結果を以下に列挙する。

（1）計算精度は, 多層路面雪水状態モデルの方が 従来の単一層路面雪水状態モデルより高い。

（2）多層路面雪水状態モデルは, 雪水厚が $20 \mathrm{~mm}$ 以下であれば，無次元計算誤差 0.06 以下（雪 水厚の計算誤差 $1.2 \mathrm{~mm}$ 以内）の精度で実験值 を再現し得る。

（3）多層路面雪水状態モデルでの雪水分割要素厚 は初期雪水厚の 2 割程度で良い。

（4）雪水温度の上昇過程において, 雪水内部の伝 導熱フラックスから純熱フラックスへの貢献 は無視できない。

（5）雪水内部の浸透水は雪水層の熱物性值（アル ベド，透過率および舗装一雪水層間の接触熱 抵抗など）に影響を及ぼすものの, 融水水に 伴う顕熱フラックスが熱収支に及ぼす影響は, 本実験条件では無視できる。
今後は, 本モデルの野外への適用性を調べるとと もに, 凍結防止剂の熱・物理・化学的影響をモデル に組み込み, 最適な凍結防止剂の散布量および時期 を前もって決定するためのツール開発に取り組む。

\section{参考文献}

1) 藤本明宏, 渡邊洋, 福原輝幸: 輻射一透過を伴 う路面薄雪水層の融解解析, 土木学会論文集, Vol.63, No.2, 2007, pp.156-165.

2 ) 藤本明宏, 渡邊洋, 福原輝幸 : 単一層路面雪水 状態モデルの適用範囲および熱的考察, 日本雪 工学会誌, 査読中.

3 ) Gradel, R. W. : The transmission of water through snow, Am. Geophs. Union 35, 1954, pp.475-485.

4 ）前野紀一, 福田正巳 : 基礎雪水学講座 I 雪水 の構造と物性, 古今書院, 1986, pp.173-174.

5 ) 山崎剛, 櫻岡崇, 中村亘, 近藤純正 : 積雪の変 成過程について：I モデル, 雪水, Vol.52, No.2, 1991, pp.115-123.

6 ）岩倉栄一, 佐藤晃三 : 積雪の熱収支と融雪モデ ルー融雪流出の基礎的研究 (I) - , 農業土木学 会論文集, Vol.154, 1991, pp.99-107. 